\title{
The work process and care production in a Brazilian indigenous
} health service

\author{
Processo de trabalho e produção do cuidado em um serviço de saúde indígena no Brasil \\ Proceso de trabajo y producción de la atención en una institución brasileña de salud indígena
}

\author{
Aridiane Alves Ribeiro \\ Giovanni Gurgel Aciole ${ }^{2}$ \\ Cássia Irene Spinelli Arantes ${ }^{2}$ \\ Jeff Reading ${ }^{3}$ \\ Donna L.M. Kurtz ${ }^{4}$ \\ Lídia Aparecida Rossi ${ }^{5}$
}

1. Universidade Federal de Goias.

Jatai, GO, Brazil.

2. Universidade Federal de São Carlos.

São Carlos, SP, Brazil.

3. University of Toronto. Toronto, Canada.

4. University of British Columbia.

Okanagan, Canada.

5. Universidade de São Paulo.

Ribeirão Preto, SP, Brazil.
Corresponding author:

Aridiane Alves Ribeiro.

E-mail: aridianeribeiro@gmail.com

Submitted on $02 / 20 / 2017$.

Accepted on 07/19/2017.

DOI: 10.1590/2177-9465-EAN-2017-0029

\section{Abstract}

Objective: To understand the constitutive elements of the work process and care production in an Indigenous Health Support Service. Methods: Case study. Systematic observation and semi-structured interviews were conducted in January and February of 2012. The participants were 10 nursing professionals of an Indigenous Health Support Center, located in Mato Grosso do Sul state, Brazil. The work process was used as a conceptual and analytical category. Results: Through interpretative analysis, the data were organized into three categories. The results showed that care production was focused on procedures and guided by rigid institutional rules and bureaucracy. The prioritization of institutional rules and procedures was detrimental to the provision of person-centered care. Conclusion: The temporary employment contracts and rigid bureaucratic organization generated a tense work environment. These aspects do not maximize the efforts of the nursing staff to provide person-centered care.

Keywords: Workforce; Health Management; Health of Indigenous Peoples; Brazil.

\section{Resumo}

Objetivo: Compreender os elementos constitutivos do processo de trabalho e a produção do cuidado em uma instituição de apoio à saúde indígena. Métodos: Estudo de caso. Procedeu-se observação sistemática e entrevistas semiestruturadas com 10 profissionais de enfermagem de fevereiro a janeiro de 2012 em uma Casa de Apoio à Saúde do Índio, Mato Grosso do Sul, Brasil. Realizou-se análise interpretativa, utilizando processo de trabalho como categoria conceitual e analítica. Resultados: Obteve-se três categorias. A produção do cuidado tem como foco procedimentos técnicos e normas institucionais rígidas. Há priorização de regras institucionais e procedimentos em detrimento do cuidado singularizado. Conclusões: O vínculo empregatício por contrato temporário e a organização burocrática geram um clima tenso de trabalho. Tais aspectos não potencializam os esforços dos trabalhadores em prestar o cuidado centrado na pessoa.

Palavras-chave: Força de Trabalho; Gestão em Saúde; Saúde de Populações Indígenas; Brasil.

\section{Resumen}

Objetivo: Comprender los elementos constitutivos del proceso de trabajo y la producción de la atención en una institución de apoyo a la salud indígena. Métodos: Estudio de caso realizado en una casa de apoyo de salud indígena, en Mato Grosso do Sul, Brasil. Fueron realizadas entrevistas semiestructuradas y la observación sistemática con 10 profesionales de enfermería. Se realizó el análisis temático, utilizando el proceso de trabajo como referencial teórico. Resultados: Emergieron tres categorías la atención se centra en procedimientos técnicos y es guiada por burocracia y normas institucionales; hay una priorización de las normas; y procedimientos institucionales a expensas de la atención centrada en el sujeto. Conclusiones: El contrato de trabajo temporal y la organización burocrática producen un ambiente tenso en el trabajo, lo que no potencializa los esfuerzos del personal de enfermería en prestar una atención centrada al indígena.

Palabras clave: Fuerza de Trabajo; Gestión en Salud; Salud de Poblaciones Indígenas; Brasil. 


\section{INTRODUCTION}

Contact with surrounding societies over time has inserted indigenous peoples into contexts permeated by interrelated environmental, cultural, and epidemiological impacts..$^{1-3}$ In Brazil, indigenous societies continue to experience the consequences of historical intervention from European colonization. The result is their social marginalization, particularly in relation to access to public health services. ${ }^{2-4}$

Healthcare for indigenous populations is also affected by cultural, social, historical, economic, and political factors. Health workers involved in indigenous healthcare constantly face perspectives that differ from the classic biomedical model prevalent in Western societies. ${ }^{5-8}$

Additionally, at healthcare centers, the quality of the provision of care is affected by the organization of the work process, such as the technological material and non-material instruments, the type of work contract, the professional training, the flexibility of work rights, and the technical division of the labor. ${ }^{9,10}$

Since aspects of the work organization greatly influence care production, ${ }^{9,10}$ we asked how the aspects of work organization influence the provision of nursing care in an indigenous health center, which is also shaped by cultural, social, and historical factors?

The purpose of this study was to understand the constitutive elements of the work process and care production in an indigenous health support service in Brazil.

\section{LITERATURE REVIEW}

\section{Indigenous Healthcare in Brazil}

Issues related to indigenous health in Brazil have begun to represent, not merely demands for improvement in the health and epidemiological profiles of indigenous people, but also policy tools for the inclusion of these communities in the national sphere, with requests for autonomy and self-management of actions and resources. ${ }^{3,9,11}$

Before the 1960s, there was no governmental institution responsible for indigenous healthcare in Brazil. In 1967, the National Indian Foundation, linked to the Justice Ministry, was created. Nevertheless, indigenous health problems were still dismissed in the country. In 1999, the Brazilian Indigenous Healthcare Policy was approved. This policy prioritized respect to indigenous peoples during the healthcare and the integration of native knowledge into the Brazilian public health system [Sistema Único de Saúde (SUS)]. ${ }^{11}$ In 2011, the Special Department for Indigenous Health, linked directly to the Ministry of Health, was created to exclusively coordinate indigenous healthcare in Brazil.

The organization of healthcare for indigenous people must recognize their human dignity, the right to individuality, and ethnic diversity. 3,6,11 The Indigenous Healthcare Policy also recommends special attention to indigenous people. In other words, the provision of care should focus on indigenous needs and integrate traditional native medicines. ${ }^{8}$
Some investigations have, however, pointed out that the indigenous healthcare knowledge and their traditional healing practices are not included in the professional care provided in the villages. ${ }^{4,5,8}$ Since the inception of the National Indigenous Healthcare Policy, the various forms of indigenous care in Brazil have not been evaluated by governmental agencies. ${ }^{11,12}$

The National Indigenous Healthcare Policy established 34 Special Indigenous Health Districts covering all Brazilian indigenous territory. The districts were created according to demographic, cultural, social, and economic aspects of the Brazilian indigenous peoples. ${ }^{11}$ In each district, the attendance flow starts in the village health service, where health promotion actions are recommended. The same health team plans and manages care provided to communities from several villages in a region.

For complex healthcare needs, indigenous people are referred to specialized health services. In these cases, an Indigenous Health Support Center [Casa de Apoio à Saúde do Índio (CASAI)] assists indigenous people in treatment/recovery periods and their family members/caregivers. ${ }^{6}$ At the CASAI, the healthcare providers are responsible for organizing and providing care for the indigenous people while they are away from their communities. ${ }^{11}$

\section{Health Practice Technologies}

In order to understand the care production in an indigenous health service, the work process perspective was used as conceptual and analytical category. ${ }^{9,10,13}$ According to this perspective, the healthcare/health work happens during the encounter between professionals and patients. The health practices take place within a specific work environment. ${ }^{9,13}$

The work process perspective also states that health workers and patients disclose different concepts regarding health and disease during the provision of care. These concepts also shape the kind of care provided in a health center. ${ }^{10,13}$ Based on this perspective, both health and disease are understood as a sociocultural process. ${ }^{10,13}$

The care is provided by healthcare professional through the use of material (technological equipment) and non-material (understanding, technological knowledge) instruments. ${ }^{9,13}$ These elements can be used to understand the organization of the healthcare provided to indigenous people within a Special Indigenous Health District. In healthcare, the use of technology occurs within the work process and encompasses knowledge and instruments, as well as the management of these elements by the people involved in the care (health professionals and patients). ${ }^{13}$

The technological instruments needed for the nursing work/ care process can be organized according to the "suitcases" of technology proposed by Merhy. ${ }^{13}$ They are: the hand suitcase, head suitcase, and relational suitcase. A nurse's hand suitcase contains "hard" technology tools, such as the stethoscope, syringe, needle, thermometer, and recording equipment. 
The head suitcase is the repository of professional expertise, for example, clinical and epidemiological knowledge. These elements can be classified as "soft-hard" technology. The relational suitcase contains "soft" technology tools, such as dialogue, respect, accountability, and bonding. ${ }^{9,13}$

The work process perspective also considers the political, cultural, economic, and social forces that traverse the work environment where the production of care is established..$^{9,10,13}$ The forces intrinsic to the work process include: social inequalities, conditions of work, and insecurity and health in the job, as well as the different concepts of the health-illness-care process shared by healthcare providers and indigenous people. . $^{4,8,9,13}$

Indigenous healthcare encompasses different types of knowledge from Public Health and other areas of expertise, such as Clinic, Epidemiology, Management and Social Sciences, of the public health field. Among other fields of knowledge, Anthropology and Psychology should be mentioned. ${ }^{14}$ The indigenous healthcare provided, however, can also show aspects from work processes focused on hard technology and bureaucracy. ${ }^{14}$ The nursing care was studied in this context of the paradox of indigenous healthcare.

\section{METHODS}

\section{Study Design and Context}

This qualitative case study was conducted in an Indigenous Health Support Center using the theoretical approach of the work process in healthcare from the Public Health field. ${ }^{9,10,13,14}$ The CASAl of the study is located in the Mato Grosso do Sul Special Indigenous Health District.

The following map (Figure 1) shows the location of the Districts in Brazil, the one numbered 19 refers to the Mato Grosso do Sul District. ${ }^{15}$

This District has a high density demographic, comprising 68,309 indigenous people. These people are distributed in 202 villages and are from 10 ethnicities - Atikum, Bororo, Cinta Larga, Guarani, Guarani Kaiowá, Guató, Kadwéu, Kinikinawa, Ofaié, Xavante and Terena. ${ }^{15}$

The CASAI of Mato Grosso do Sul District provides care to approximately 40 indigenous people and companions (parents and/or caregivers) per day, from 10 ethnic groups. Nursing services are available 24 hours a day. The nursing team is composed of one nurse (who has bachelor's degree in nursing) and nine nursing technicians (who have two years of nursing training). All members of the nursing staff at the CASAl were considered to be eligible for participation in this study.

Nursing care is organized functionally and spatially into two sectors: the scheduling sector and the nursing station. The CASAI is responsible for providing care, assistance, and support to the indigenous people, including patient transport and consultation and examination scheduling. The nurse and a nursing technician work in the scheduling sector, conducting activities connected to the scheduling of appointments, examinations, and other
Figure 1. Map of the distribution of Special Districts of Indigenous Health in Brazil "Adapted from Secretaria Especial de Saúde Indígena ${ }^{15 " .}$

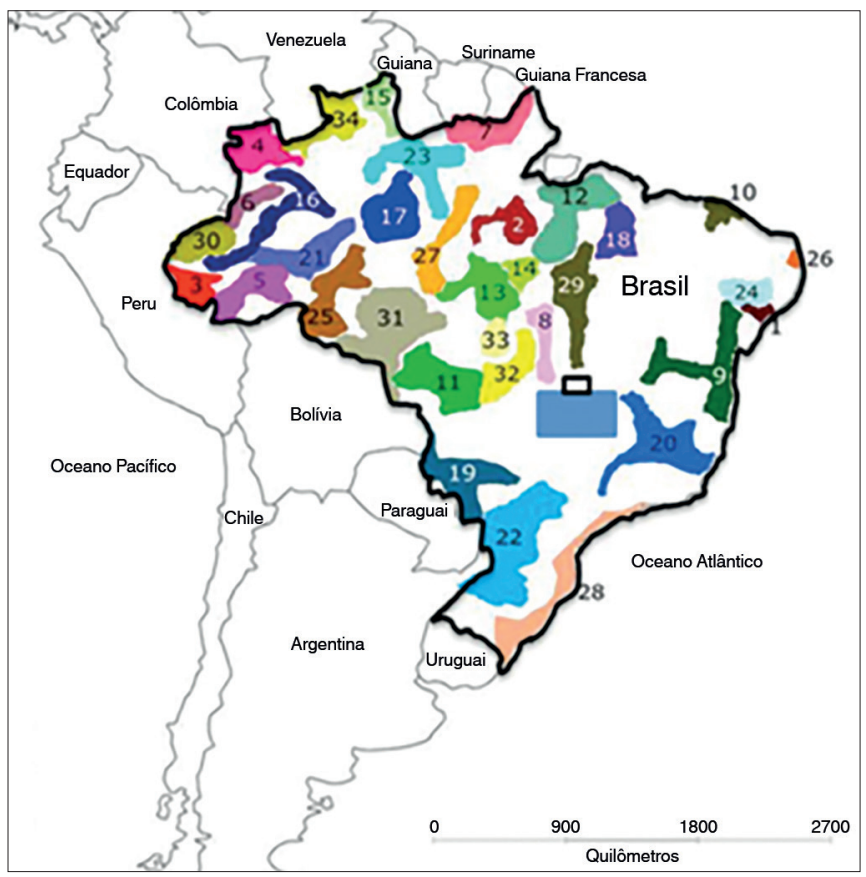

procedures. The scheduling sector functions eight hours a day from Monday to Friday. The nursing technicians, whose activities are performed at the nursing station, work 12-hour shifts followed by 36 hours off. This work regime covers daytime and nighttime periods. The nursing station staff are responsible for providing direct care to users (patients) and guiding the indigenous people within the complex organization of the city's health services.

\section{Fieldwork}

The data collection was carried out by means of interviews and documental analysis, from January to February of 2012. The systematic observation was guided using Merhy's ${ }^{13}$ analysis flowchart, which provides a patient-centered approach to the examination of the work process and care provision in a health service. $^{9}$

One of the researchers observed the operation of the CASAl during the morning, afternoon, and evening shifts on different days of the week (including weekends and holidays). The observations, recorded in a field diary, included workers' gestures, habits, and customs. These observations provided data that confirmed or contradicted information obtained in the formal interviews.

The semi-structured interviews included the following questions:

What does working at CASAI mean for you?

Please, tell me about your relationship with the people you take care of at CASAl;

Could you please tell me what kinds of skills are needed to work and/or to take care of indigenous people at CASAI? 
Please, tell me about your relationship with your colleagues; Could you please describe your everyday activities at CASAI and how you perform them?

To ensure confidentiality and anonymity, the interviewees were identified using the letter $E$, followed by a number corresponding to the order in which the interviews occurred (E.1, E.2... E.10). The gender was also specified in the identification of the statements of the interviews, using $\mathrm{M}$ for Male and $\mathrm{F}$ for Female. For ethical reasons, the professional classification of the workers was not specified in the presentation of the results.

Documents describing relevant institutional rules and regulations, available at the CASAI, were also analyzed to collect data and understand the local operation. The main documents included in this analysis were the Indigenous Healthcare Policies and the 2009-2011annual management reports for the Mato Grosso do Sul Special Indigenous Health Districts. ${ }^{16-18}$ Documental analysis was used in the data interpretation to complement, support, and contrast the information from the observational evidence.

\section{Analysis}

The data analysis was performed according to Thorne, ${ }^{19}$ as follows:

i) reading of the material (observational notes, interview transcripts, and policy documents);

ii) extraction of interrelated (complementing, supporting and contrasting) information related to the study;

iii) definition of pre-categories according to the research objectives and theoretical framework; and

iv) inference, which allowed an understanding of the study object. After the identification of the main meanings, the pre-categories were refined to thematic categories, which arose from the analyses.

In order to assure methodological rigor during investigations with indigenous people, it is important for the researcher to be reflexive during all the steps of the investigation. There are different meanings for reflexivity; the one that was adopted for this study is from the Anthropological field. It means the impact/influence of the research process on the researcher and vice versa. ${ }^{20}$ During the fieldwork, the main researcher, in addition to assuming her prejudice and bias, took into account the historic process and her concepts and values. This perspective of self- awareness allowed her to clean the interpretative lent considering the purpose of the investigation. ${ }^{20}$ From the self-awareness process, the observation of the huge study context became more aligned with the aims of the study. This aspect contributed to the rigor of the research analyses. ${ }^{20}$

\section{Ethical Approval}

The Human Research Ethics Committee of the Federal University of São Carlos, Brazil, approved this study (No. 384/2010). The researcher informed the participants about the study. All respondents spoke the Portuguese Language and all of them were able to understand and sign the Consent Term.

\section{RESULTS}

The results are grouped into three thematic categories representing the key elements of the work process and care production at the CASAI: 1. employment contracts; 2. object and tools of the work process; and 3. care production and work relationships.

Before presenting the thematic categories, it is important to characterize the participants and their employment contracts. All 10 nursing staff members participated in the study, with a total of one nurse and nine nursing technicians. They ranged in age from 25-56 years. Six of the participants were female. Seven respondents were married and nine owned their own residences and cars. All the participants were non-indigenous.

Only two staff members had received information about indigenous healthcare during their bachelor's degree in nursing and 2 years of nursing training, respectively. Only two of the team had previously worked in other indigenous care services, specifically in villages. For the others, the CASAI provided the first experience of caring for indigenous people. It was observed that no training program had been provided by the CASAI for the nursing professionals. This was confirmed in the interviews. All the participants reported that they had received no education on indigenous populations or their healthcare since joining the human resources framework of the CASAI workforce.

The healthcare providers and indigenous patients had experienced cultural alienation during some moments of the care, as evidenced by the following statements and field observations:

[...] You have situations in which you make contact with
the culture of the indigenous people. So, there are certain
moments in which there's nothing you can do [...] (E.6, F).

[...] We start to work with prejudice. We change much as we work here, we changed our ideas [...] (E.7, F).

[...] In conversation with one of the healthcare providers, he said that indigenous people are different from nonindigenous people. He also said that some indigenous people are clean and others are quite dirty, they come to the CASAl with only the clothes on their back. The worker concluded that we, non-indigenous people, need to understand and to like indigenous people, otherwise there is no way to help them [...] (Field diary).

The lack of training of the professionals contributed to difficulties in establishing care reflecting the needs of the indigenous people. One of the healthcare providers at the CASAI recognized the importance of ongoing education:

[...] Each ethnic group has its own way of life. There is an individual ritual. There are different religions. I believe that if we knew more about these issues, it would be easier to deal with the differences [...] I think we, non-indigenous people, we should always study the indigenous traditions $[\ldots](E .10, F)$. 


\section{Employment Contracts}

The type of employment contract is another key aspect of the work process in the health service. In Brazil, workers are hired though private services or government agencies, such as in the case of public schools, public universities and public hospitals. The positions offered directly by Brazilian public health services offer more guarantees in terms of workers' social rights, for example, good salaries, workplace safety, and job security until retirement.

To obtain a government-funded position in the public health service, applicants must complete a complex evaluation process. In contrast, positions in the private health service have few or no guarantees, being more vulnerable to economic circumstances. For example, workers may be dismissed due to a market crisis or because the industry needs to cut operational costs.

Although CASAls are part of the federal public agency, nine interviewees had contracts though a non-governmental organization (private service). Only one worker was contracted under a public examination regime, and was the longest serving worker among interviewees in the CASAI. The private employment contracts did not provide the same guarantees as the governmental contract, which led to insecurity (fear of being fired) in the work environment. The following statement and field diary excerpt exemplify this issue:

[...] We, workers, we do everything according to rules they have here. And we cannot do many different things. I am afraid, because we are contracted just for one year [...] (E.9, F).

[...] The (labor) contract, that is renewed annually, causes insecurity. Forgetting to record some event may be a cause for dismissal or non-renewal of the contract [...] (Field diary).

\section{Object and Tools of the Work Process}

The nursing staff at the CASAI considered the procedures (guided by rules) and activities centered on the procedures as the work objects. The following statements show this aspect:

[...] The first thing we start to do is to prepare the medication from seven in the morning. We administer the medication and measure the vital signs. After the dressings, we begin to prepare the materials so we can do the next dressings [...] (E.2, M).

[...] From the moment that I take over the shift I check whether patients are even within the CASAI, I go from room to room, greeting and talking to them. Then I start preparing medication and reports [...] (E.10, F).

Another aspect of the work process is related to the tools used and the organization of the work. A rigid routine exists and is regulated by scheduling. That is, the activities of the health professionals are pre-established by the scheduling sector staff through the day agenda. The nursing station workers use the agenda to guide their actions during their shifts, as illustrated by the following statements:

[...] We have to satisfy the rule that is in the schedule, in our Day Agenda [...] (E.3, F).

[...] The nursing staff, after recording everything that happens with the patient, need to report all the details again on paper for the Scheduling Sector [...] (E.10, F).

The provision of care lost its potential to encompass the needs of the indigenous people because the determinations of the rules and daily agenda restricted the workers' practice due to not having time to interact with the indigenous people, to build trust and rapport. The routine, pre-established by other nursing staff through the Day agenda, affected the self-governability of the health professional that provided the face-to-face care to the indigenous patients.

\section{Care Production and Work Relationships}

It is important to highlight the purposes attributed by the health professionals to their work. Despite the rules that the nursing staff have to follow, they attributed different purposes to their work. For them, the main aim of their work was to support indigenous people at the CASAI, as can be noticed in the following statements:

[...] My purpose is, let's say, that the patient recovers [...] that they take the medicine, and recover [...] (E.3, F).

[...] The care is support and help for the patient in general. I try to do the best to help the indigenous people; the purpose is to help [...] (E.9, F).

[...] I am here to provide care, to give medication, to welcome him [the patient] when he comes from a hospital or when he comes from a medical consultation, I think the purpose is the care $[\ldots](E .2, M)$.

The nursing staff expressed willingness to try to overcome the strict rules, as demonstrated by the following statements and field diary excerpt:

[...] We need to have with a friendly approach to the patients here [at the CASAl] without imposing rules on them. In the course of time, we build trust between us $[\ldots](E .5, M)$.

[...] I think that the care of indigenous people [at the CASAI] involves looking into their eyes, touching them. When you talk and show that you are interested in their problems, the care is more effective, there is a relationship of trust $[\ldots](E .7, F)$.

[...] Although the health professionals have a lot of forms to complete, as soon as an indigenous person asks for 
any kind of help, someone on the nursing staff stops what she or he is doing to goes to support the person [...] (Field diary).

\section{DISCUSSION}

Indigenous healthcare demands special attention from health professionals to prevent further silencing, labeling and ignoring of their health concerns. ${ }^{5-8,21}$ This issue was not a high priority in the teaching and learning processes of the study participants.

The CASAI provided no training program for the nursing professionals, which contradicts the ideas advocated by researchers in the field ${ }^{5-8,21}$ and the recommendations of the Brazilian Indigenous Healthcare Policy. This policy states that care provided by health professionals should incorporate the practices of indigenous medicine. . $^{8,11}$

The implementation of the Brazilian Indigenous Healthcare Policy is linked to the attitudes and practice of the professionals. If they are unaware of the patient's culture, including Aboriginal history and colonization, the healthcare providers will not know how to proceed when presented with an indigenous or multicultural perspective. ${ }^{7,8,11,21}$ Without knowledge of indigenous diversity, the work/care process will create "culture shock," or cultural estrangement between the care actors (patients and the professionals who serve them). ${ }^{2,7,8,11,14}$

The data showed a lack of familiarity among the nonindigenous workers regarding indigenous culture. A subtle construction of mutual understanding was developed within the quotidian social relationships between the care actors in the work and care processes. This issue reflects the need for familiarity with traditional indigenous medicine among the non-indigenous health professionals, acquired through ongoing education.

The participants of this study spoke of the need for ongoing education to minimize their lack of knowledge about indigenous culture and medicine. The health workers may understand better the indigenous traditional health practices after a time working at health centers within the villages. ${ }^{7}$

The workers from the CASAI, however, do not live in the villages. This aspect does not help them to get closer and have a deep enough understanding of the culture and traditions of the indigenous people who are attended at the CASAI. Additionally, many ethnic groups are supported by the CASAI. Thus, the healthcare providers need to deal with several different indigenous beliefs and concepts about the healing process. More initiatives and collaborations are required to put the health staff from the CASAI in contact with indigenous knowledge. Professionals who work in other parts of Brazil have also mentioned a lack of training in indigenous healthcare as a problem. ${ }^{4,8,11}$

Many healthcare providers working in indigenous and rural areas worldwide are unprepared to perceive the need for specific action within these populations. ${ }^{2,11,21,22}$ Due to the prevalent biomedical professional formation, the majority of health workers are not open to understanding and accepting the therapeutic strategies used by indigenous people or their interpretations of illness and the healing process. ${ }^{7,21,22}$ In this context, respect for integration of indigenous health practices during the care process become challenging.

Ongoing education of healthcare staff is important to define the roles of each person in the health production process, as it promotes improvement of social relationships in the quotidian context of a health service. ${ }^{23}$ Consequently, the healthcare would be built on the attributes of indigenous health and cultural identity within a historical, cultural, and sociopolitical context. ${ }^{21}$

The provision of care to indigenous people that reflects their needs should also include the consideration of native culture, knowledge, and protocols of ceremonies and traditions. Institutional support is important in this sense, as it can promote skills to overcome the unfamiliarity and estrangement of non-indigenous health professionals in relation to traditional indigenous medicine. , $^{23-25}$

The employment contracts of the health professionals affected the work process. Temporary contracts and rigid bureaucratic organization created a tense work environment at the CASAI. Similar to the participants of the present study, healthcare workers at the CASAl of São Paulo, Brazil, reported that they felt insecure and unable to fully perform their functions. ${ }^{24}$ Professionals at the CASAI work in an insecure environment and constantly feel on the verge of possible dismissal. ${ }^{24}$ They work according to the strict rules determined by the scheduling sector, limiting the amount of time with which to talk and construct trust and rapport with those they are providing care for.

The fear and tension expressed in the statements of the interviewees reflect feelings of powerlessness in situations that they had experienced. The insecurity related to the employment contracts contributes to a high turnover, which is a problem in terms of guaranteeing the quality of healthcare, ${ }^{26,27}$ especially indigenous healthcare. ${ }^{5,11}$ The feeling of professional instability is a manifestation and/or consequence of the breakdown of the social protection in the workplace, which reflects the deregulation and insecurity of the work in this field. ${ }^{26,27}$ The work process at the CASAI studied in this research reflects greater flexibility of employment, maximized by the recruitment method under these care/work production conditions.

The imposition of a commercial logic on healthcare services devalues the work by maximizing the use of the workforce and minimizing the social protection. ${ }^{26,28}$ With the transfer of responsibility for healthcare from the federal to the municipal level in 1993, municipalities and cities became responsible for contracting personnel in Brazil. ${ }^{27}$ However, the Brazilian Fiscal Responsibility Law, enacted in 2000 , based on neoliberal ideology, appears to restrict municipal autonomy in personnel recruitment. ${ }^{29}$ Such factors, together with the lack of guidance of some municipal managers and political and economic interests, have led to an increase in recruitment through partnerships with non-governmental organization, and cooperatives. ${ }^{28}$ The effects of this recruitment context are enhanced in the indigenous 
healthcare system, as the Brazilian government has transferred actions related to indigenous healthcare to the private sphere with little or no regulation. ${ }^{4}$

These findings indicate that, for indigenous health services, the state does not mean "public"; the private service and its logic can be predominant in the public indigenous services. ${ }^{29}$ The incorporation of the logic of market profitability and state disengagement have resulted in the technification of the health practice ${ }^{27}$ with little attention given to optimization in terms of the needs of the care actors (healthcare providers and indigenous patients). The bureaucratization of healthcare management and the rigidity of government action in this context has culminated in the failure of many non-governmental organizations. ${ }^{4}$ Such circumstances directly influence the organization and delivery of healthcare, ${ }^{27}$ especially at the CASAI. The provision of care at the CASAl is permeated by such forces, which are antagonistic to the recognition of individuality and culturally holistic care.

The imposition of administrative rules and technical standards on the nursing team indicates the existence of vertical power schemes based on Taylorism. ${ }^{26-29}$ According to this system of scientific management principles, elaborated by Fred Taylor, the workers became more productive when they follow a machinelike routine and eliminate avoidable motion. ${ }^{30}$

Merhy ${ }^{9,13}$ used Taylorism ideas ${ }^{30}$ as a way to explain how intense domination of work in manufacturing can also be reproduced in the provision of care at a health center. Similar to Taylorism, depending on rules and political forces, the health worker can be forced to provide purely technical and biomedical care. In this way, there are few possibilities for health professional to provide holistic care reflecting the needs and beliefs of indigenous people..$^{9,13}$

The statements of the interviewees indicate prioritization of the technical procedure, followed by the regulatory procedure. In these cases, the work objects were not focused primarily on the person, but rather on accountability and administration of the process. Healthcare at the CASAI formed intercessional relationships centered on the object. ${ }^{13}$

Care production occurs in meetings between workers and users, and may be shared or objectal. ${ }^{13}$ Shared care involves both actors; healthcare providers and patients share their wants and needs. Care centered on the object occurs when the needs of the user are external to the relationship between health provider and patient, ${ }^{13}$ i.e., the care is directed only toward the biological body, the pathology. The relationship centered on the object established in the care production at the CASAI reflects the notion that the intervention object is composed of the performance of technical procedures guided by institutional rules. ${ }^{9}$

The mechanical, repetitive, and rationalized actions of the nursing staff configure care restrained by a work process that privileges and values rules and procedures. ${ }^{9,23}$ The creative ability of the worker and the potential opportunity to provide person-centered care cannot resist the deterioration resulting from a fragmented practice in a structured health service. ${ }^{23,28}$
In relation to health technology, the nursing workers at the CASAI predominantly used the hand and head suitcases in the care production. ${ }^{13}$ The focus on procedures, which is the work object for the healthcare providers at the CASAl, requires structured knowledge (e.g., clinical expertise, anatomical expertise). This kind of knowledge is contained within in the head suitcase. The head suitcase of the professionals contains technical-organizational knowledge ${ }^{13}$ which is constructed in the quotidian work process. It also includes awareness in relation to the indigenous reality learned in the everyday provision of care at the CASAI. ${ }^{7}$

The tools of the hand suitcase of the nursing staff at the CASAl are represented by the thermometer, stethoscope, sphygmomanometer, dressing material, and nursing register material. ${ }^{9,13}$ The work process at the CASAI also involved soft technologies, which are linked to relational technologies from the relational suitcase. The predominant arrangement between soft-hard (head suitcase) and hard technologies (hand suitcase) contributes, in most cases, to reduce health workers to mechanized production. ${ }^{9,13}$

According to the participants and observations, the main purposes of care provision at the CASAI were to help and to support the indigenous people. However, the bureaucratic work process was superimposed on the wishes and subjectivities of the workers. The nursing staff intended to maintain and negotiate positive relationships with the indigenous people at the CASAI. Nevertheless, their creative potential and self-governability were limited due to the bureaucratic organization of the work process.

Thus, a paradox exists in the care production at the CASAI. The National Indigenous Healthcare Policy advocates the provision of indigenous-centered care. The CASAl, however, an organization directly linked to the state and representative of the Indigenous Healthcare Policy, supports a work process that values procedures instead of indigenous needs and beliefs.

Modification of the hegemony centered on rules and procedures is necessary. The work environment at the CASAl needs to provide institutional support and ongoing education to the health workers allowing them to see and hear others, ${ }^{7}$ and to consider the cultural, experiential, and social aspects underlying the disease process and/or health needs of the indigenous people.

\section{Limitations}

One of the limitations of this study is that the indigenous people who were undergoing treatment at the CASAI during the data collection did not participate in the study due to ethical issues. In order to understand the healthcare provided to native people, it is fundamental that they are properly represented in the research.

The findings of this study cannot be generalized beyond the study sample due to the qualitative nature of the study and the small sample size. However, the credibility and validity of the categories were supported by the methodological and interpretive rigor employed throughout the research. 


\section{CONCLUSIONS AND IMPLICATIONS FOR PRACTICE}

The work process arrangement impacted the quality of care provide by nursing staff at the indigenous health center. Results from the analysis support the notion that the employment contracts of the professionals, established though a non-governmental organization and temporary in nature, do not provide the same guarantees as permanent contracts obtained through the Brazilian public examination regime.

The temporary employment contracts though a nongovernmental organization can save money, however, make the work environment insecure, due to the fear of being dismissed. Consequently, the work process does not currently contribute to the provision of care based on the needs of indigenous people.

The findings of this study allow reflections regarding the logic of management of the work process in indigenous health services in order to promote holistic and person-centered care for indigenous populations. The findings also make a major contribution to the literature and have important implications for policy and healthcare service research regarding indigenous individuals, families and communities. Further studies on the care and work process in indigenous health services of Brazil and CASAls are important, with these involving indigenous people, workers and managers.

\section{ACKNOWLEDGMENTS}

We also thank all workers of the Indigenous Health Support Center, and in particular the nursing staff that promptly accepted to support this study, give attention and information required by the principal investigator in the fieldwork.

\section{REFERENCES}

1. Elias B, Mignone J, Hall M, Hong SP, Hart L, Sareen J. Trauma and suicide behaviour histories among a Canadian indigenous population: An empirical exploration of the potential role of Canada's residential school system. Soc Sci Med [Internet]. 2012; [cited 2016 Jul 10]; 74(10):1560-9. Available from: http://dx.doi.org/10.1016/j. socscimed.2012.01.026

2. Montenegro RA, Stephens C. Indigenous health in Latin America and the Caribbean. Lancet [Internet]. 2006 [cited 2016 Jun 10]; 367(9525):1859-69. Available from: https://www.ncbi.nlm.nih.gov/ pubmed/16753489. DOI: 10.1016/S0140-6736(06)68808-9

3. Babis $D$. The role of civil society organizations in the institutionalization of indigenous medicine in Bolivia. Soc Sci Med [Internet]. 2014; [cited 2016 Jun 10]; 123:287-94. Available from: https://www.ncbi.nlm.nih. gov/pubmed/25043560. DOI: 10.1016/j.socscimed.2014.07.034

4. Pontes AM, Garnelo L, Rego S. Reflection on moral issues in the relation between Indigenous people and health services. Rev Bioet. 2014; 22(2):337-46. DOI: http://dx.doi.org/10.1590/1983-80422014222015

5. Ribeiro AA, Fortuna CM, Arantes CIS. Nursing work in an indigenous support institution. Texto Contexto Enferm [Internet]. 2015 Jan-Mar; [cited 2016 Nov 14]; 24(1):138-45. Available from: http://www.scielo.br/ scielo.php?script=sci_arttext\&pid=S0104-07072015000100138. DOI: http://dx.doi.org/10.1590/0104-07072015002480013
6. Brant-Castellano M, Reading J. Policy Writing as Dialogue: Drafting and Aboriginal chapter for Canada's Tri-council Policy Statement: Ethical Conduct for Research Involving Humans. Int Indig Policy J [Internet] 2010; [cited 2016 Nov 14]; 1(2):[about 20 screens]. Available from: http://ir.lib.uwo.ca/iipj/vol1/iss2/1. DOI: 10.18584/iipj.2010.1.2.1

7. Pereira PPG. Limites, traduções e afetos: profissionais de saúde em contextos indígenas. Mana [Internet]. 2012; [cited 2017 Mar 25]; 18(3):[about 20 screens]. Available from: http://www.scielo.br/scielo. php?script=sci_arttext\&pid=S0104-93132012000300004. DOI: http:// dx.doi.org/10.1590/S0104-93132012000300004

8. Pontes ALM, Rego S, Garnelo L. The differentiated care model in the Special Indigenous Health Districts: reflections based on Alto Rio Negro in Amazonia State, Brazil. Ciênc Saúde Coletiva [Internet].2015; [cited 2017 Mar 25]; 20(10):[about 12 screens]. Available from: http://www.scielo.br/scielo.php?script=sci_arttext\&pid=S1413-81232015001003199. DOI: 10.1590/1413-812320152010.18292014

9. Franco TB, Merhy EE. Cartographies of Work and Healthcare. Tempus (Brasília). [Internet] 2012; [cited 2016 Jul 10]; 6(2):15163. Available from: http://tempus.unb.br/index.php/tempus/article/ viewFile/1120/1034

10. Marx K. O Capital: Crítica da Economia Política: Livro I: o Processo de Produção do Capital. Tradução de Rubens Enderle. São Paulo: Boitempo; 2013. 574 p.

11. Diehl EE, Langdon EJ, Dias-Scopel RP.The contribution of indigenous community health workers to special healthcare for Brazilian indigenous peoples. Cad. Saúde Pública [Internet]. 2012; [cited 2016 Jul 10]; 28(5):819-31. Available from: http://www.scielo.br/scielo. php?script=sci_arttext\&pid=S0102-311X2012000500002. DOI:http:// dx.doi.org/10.1590/S0102-311X2012000500002

12. Langdon EJ.The dialogues between anthropology and health: contributions to public policies. Ciênc Saúde Coletiva. [Internet]. 2014; [cited 2017 Mar 22]; 19(4):[about 11 screens]. Avalaible from: http://www.scielo.br/scielo.php?script=sci_arttext\&pid=S1413-81232014000401019. DOI: 10.1590/1413-81232014194.22302013

13. Merhy EE. Em busca do tempo perdido: a micropolítica do trabalho vivo em saúde. In: Merhy EE, Onocko R, orgs. Agir em saúde: um desafio para o público. 3aㅡ ed. São Paulo (SP): Hucitec; 1997. p. 71-112.

14. Franco TB. Modelo assistencial para a saúde indígena: DSEI-MG/ES. 2004. [cited 2016 Dec 12]. Available from: http://sis.funasa.gov.br/portal/ publicacoes/pub42.pdf

15. Ministério da Saúde (BR). Conheça o DSEl. 2011. [cited 2017 Aug 17] Available from: http://portalsaude.saude.gov.br/index.php/o-ministerio/ principal/leia-mais-o-ministerio/70-sesai/9540-conheca-o-dsei

16. Fundação Nacional da Saúde. Annual Management Report 2008 Special Indigenous Health Districts-Mato Grosso do Sul District. Brazil. Campo Grande: Coordenação Regional de Mato Grosso do Sul; 2009. 20 p.

17. Fundação Nacional da Saúde. Annual Management Report 2009: Special Indigenous Health Districts-Mato Grosso do Sul District. Brazil. Campo Grande: Coordenação Regional de Mato Grosso do Sul; 2010. $25 \mathrm{p}$.

18. Fundação Nacional da Saúde. Annual Management Report of CASAI (Mato Grosso do Sul District): 2010. Campo Grande: Ministério da Saúde, Secretária Especial de Saúde Indígena; 2011. 22 p.

19. Thorne S. Interpretative Description. 2nd ed. New York: Routledge; 2016. 320 p.

20. Emmerich N. For an Ethnomethodology of Healthcare Ethics. Health Care Anal [Internet]. 2013; [cited 2016 Oct 27]; 21(4):372-89. Available from: http://link.springer.com/article/10.1007\%2Fs10728-012-0202-7. DOI: $10.1007 / \mathrm{s} 10728-012-0202-7$

21. Kurtz DLM, Turner D, Nyberg J, Moar D. Social Justice and Health Equity: Urban Aboriginal Women's Action for Health Reform. Int J Health Wellness Soc [Internet]. 2014; [cited 2016 Oct 27]; 3(4):13-26. Available from: http://ijw.cgpublisher.com/product/pub.198/prod.155/m.2 
22. Rohatinsky NK, Jahner S. Supporting nurses' transition to rural healthcare environments through mentorship. Rural Remote Health [Internet]. 2016; [cited 2016 Oct 27]; 16:3637. Available from: http:// www.rrh.org.au/articles/subviewnew.asp? ArticlelD $=3637$

23. Ceccin RB, Merhy EE. Intense micropolitical and pedagogical action: humanization between ties and perspectives. Interface (Botucatu) [Internet]. 2009 [cited 2016 Jun 10]; 13(Suppl 1):531-42. Available from: http://www. scielo.br/scielo.php?script=sci_arttext\&pid=S1414-32832009000500006. DOI: http://dx.doi.org/10.1590/S1414-32832009000500006

24. Gonçalves LJM. Na fronteira das relações de cuidado em saúde indígena. São Paulo: Annablume; 2011.123 p.

25. Waterworth P, Rosenberg M, Brahan R, Pescud M, Dimmock J. The effect of social support on the health of Indigenous Australians in a metropolitan community. Soc Sci Med [Internet]. 2014; [cited 2016 Oct 27]; 119:139-46. Available from: http://www.sciencedirect.com/science/ article/pii/S0277953614005619. DOI: http://dx.doi.org/10.1016/j. socscimed.2014.08.035

26. Melo CMM, Carvalho CA, Silva LA, Leal JAL, Santos TA, Santos HS. Nurse workforce in state services with direct management: Revealing precarization. Esc Anna Nery [Internet]. 2016 Jul-Set; [cited 2016 Jan
15]; 20(3):e20160067. Available from: http://www.scielo.br/pdf/ean/ v20n3/en_1414-8145-ean-20-03-20160067.pdf. DOI: 10.5935/14148145.20160067

27. Morosini MVGC. Precariousness in the labor market: particularities in the Brazilian health sector. Trab Educ Saúde [Internet]. 2016; [cited 2017 Jan 16]; 14(Suppl 1):5-7. Available from: http://www.scielo.br/scielo. php?script=sci_arttext\&pid=S1981-77462016000400005\&Ing=en\&nr m=iso. DOI: http://dx.doi.org/10.1590/1981-7746-sip00131

28. Faria HX, Dalbello-Araujo M. Precariousness of work and care productive process. Mediações. 2011;16(1):142-56. DOI: 10.5433/2176-6665.2011v16n1p142

29. Aciole GG. As desventuras de público no país dos privatas. In: Ferla AA, Ramos AS, Leal MSC, orgs. VER-SUS Brasil: caderno de textos do VER-SUS/Brasil. Porto Alegre (RS): Rede Unida; 2013. p. 72-84.

30. Mishra A, Agnihotri V, Mahindru DV. Application of Maynard Operation Sequence Technique (M.O.S.T) at Tata Motors and Adithya Automotive Application Pvt Ltd. Lucknow for Enhancement of Productivity - A Case Study. Global J Res Eng B Automotive Eng [Internet]. 2014; [cited 2016 Oct 20]; 14(2):[about 8 screens]. Available from: http://www. engineeringresearch.org/index.php/GJRE/article/viewFile/1058/990 